\title{
ЛІТЕРАТУРОЗНАВСТВО
}

\section{СИМВОЛ ЧІЧКИ В НОВЕЛІСТИЦ ВАСИЛЯ ТКАЧУКА}

\author{
АННА ГОРНЯТКО-ШУМИЛОВИЧ \\ Університет імені Адама Міцкевича, Познань - Польща \\ anna.horniatko@wp.pl; ORCID: 0000-0003-1625-6193 \\ SYMBOL CZICZKI W NOWELISTYCE WASYLA TKACZUKA \\ ANNA HORNIATKO-SZUMIŁOWICZ \\ Uniwersytet imienia Adama Mickiewicza, Poznań — Polska
}

\begin{abstract}
STRESZCZENIE. W artykule prześledzono symbol cziczki w nowelistyce ukraińskiego pisarza lat 30. XX w. Wasyla Tkaczuka. Wykazano, iż słowo cziczka jako huculski dialektyzm odgrywa $\mathrm{w}$ twórczości nowelisty ważną rolę, będąc swoistym lejtmotywem pojawiającym się niemal w każdym jego utworze. Cziczka to święty kod rodu huculskiego pełniący rolę talizmanu, który towarzyszy Hucułom, niczym wyszywka, w czasach radości i smutku, co po mistrzowsku słowem namalował Wasyl Tkaczuk.
\end{abstract}

Słowa kluczowe: symbol cziczki, nowelistyka, obraz Huculszczyzny, literatura ukraińska.

SYMBOL CHICHKA IN THE NOVELS WRITTEN BY VASYL TRACHUK

\author{
ANNA HORNIATKO-SZUMIŁOWICZ \\ Adam Mickiewicz University, Poznan — Poland
}

\begin{abstract}
The article focuses on the analysis of symbol chichka in the novels of the Ukrainian writer of the 30-ies of the XXth century Vasyl Tkachuk. It has been proved that the word chichka, as a hutsul dialectal word, plays an important role in the creative work of the novelist, being a peculiar leitmotif, which is present in almost every work of the writer. Chichka - is a sacred code of the hutsul ethnic group, that functions as oberih, as well as embroidery, which guides the hutsuls in the periods of joy and grief. All the above mentioned facts are depicted by Vasyl Tkachuk in his works.

Key words: symbol chichka, novel studies, image of Hutsul region, Ukrainian literature.

$\Gamma$ Туцульщина з іï непідробною аурою, унікальними традиціями була предметом зацікавлення багатьох українських письменників. Першовідкривачами гуцульської теми в новій українській літературі стали, як відомо, представники „Руської трійці” - Іван Вагилевич, Яків Головацький та Маркіян Шашкевич. Гуцульщину як край презентували у своїх творах серед інших і Симон Воробкевич, Михайло Павлик, Микола Устиянович, Юрій Федькович, Іван Франко, Леся Українка, Михайло Коцюбинський, Василь Стефаник, Марко Черемшина та ін. У літературі першої третини XX ст. Гуцульщина стала темою творів численних письменників і поетів, зокрема Христини Алчевської, Василя Гренджа-Донського, Дмитра Загула, Богдана Лепкого, Гната Хоткевича, Олександра Олеся, Василя Пачовського, Богдана-Ігоря Антонича, Юрія Шкрумеляка ${ }^{2}$
\end{abstract}

${ }^{1}$ Див. детальніше про це: Т. Б. Бикова, „Верховино, світку ти наш...”: гуиульський текст украӥнської літератури першої третини ХХ століття, Київ 2015. 
"Гуцульські тексти" українських письменників нерідко включали елементи діалектної мови, завдяки чому набували автентичності, точно відтворюючи карпатські реалії гуцулів².

Серед численних мовних особливостей співців Гуцульщини на окрему увагу заслуговує слово чічка - гуцульський діалектизм. Згідно зі Словником української мови, чічка - діалектне 'квітка' даному в 2012 році Словнику українських говірок Карпатського регіону (1912). Його укладач Дмитро Савчук розширює семантичне поле слова, пояснюючи його як 'квітка; все, що гарне' і водночас підкреслюючи його “чужість” в інших регіонах України ${ }^{4}$. На веб-платформі Україна модна (UaModna), провідним гаслом якого $є$ такий вислів: „Модно бути креативним, модно бути унікальним, модно бути українцем!”, з'явилася лексема чічка поміж “модних слівець”, які варто вживати

Незважаючи на згадану вище “чужість" діалектизму чічка, письменники його широко використовують, звертаючись до гуцульського говору. Так, Іван Франко вживає лексему чічка для підкреслення вродливості дитини. У його Перехресних стежках (1900) селянин з невщухаючим жалем згадує свого померлого сина, порівн.: - Сей хлопчик був мій одинак... три роки мав... як чічка... ${ }^{6}$. Інший письменник Гнат Хоткевич у романі Камінна душа (1911) із захопленням описує гуцульські краєвиди, невід'ємним складником яких є гірські квітки - чічки: Все зелене доокола. А на тлі иъього зеленого моря, мрійних контурів далеких верхів, мов рухливі чічки барвисті, посіялися гуцули й гуцулки .

Василь Стефаник, герої творів якого розмовляли покутсько-буковинським говором, що на заході межує із гуцульським, діалектизм чічка вживає у двох новелах: Виводили з села та Сини. У першій з них сільська громада, яка проводжає рекрута, бачить зоряне небо, схоже на заквітчаний майданчик: Над ними розстелилося осіннє склепіння небесне. Звідзи мерехтіли, як золоті чічки на гладкім залізнім тоиі ${ }^{8}$. У другому творі сини, які пропали на війні, покинули напризволяще старого батька Максима, у якого ще й хочуть відібрати землю. Старий

\footnotetext{
${ }^{2}$ Примітка. Як зазначають дослідники, гуцульський діалект має довгу історію використання в українській художній літературі, започатковану в новій белетристиці Юрієм Федьковичем. Традицію вкраплювання гуцульських діалектизмів у літературний текст успішно продовжували такі письменники, як Іван Франко, Михайло Павлик, Михайло Коцюбинський, Марко Черемшина, Василь Стефаник, Сидір Воробкевич та ін. Поміж сучасних літераторів, які звертаються до джерел гуцульського говору, назвемо Віру Вовк, Юрія Андруховича, Марію Римар, Василя Шкургана, Юрка Іллєнка та ін. Слово чічка вживають головно на позначення певного виду прикрас або аксесуара, під час деталізованого опису гуцульського одягу, а також для означення дівочої краси. Див.: напр. В. Грещук, Гуиульський діалект у мові сучасної української літератури, [в:] „Вісник Прикарпатського національного університету. Філологія”, 2012, вип. XXXII-XXXIII, гол. ред. В. В. Грещук, с. 214-219.

${ }^{3}$ Див.: Словник української мови, в 11 томах, за ред. І. К. Білодіда, Київ 1970-1980, т. 11, 1980, c. 343.

${ }^{4}$ Див.: Словник украӥнських говірок карпатського регіону: Пояснення та походження слів, уклад. Д. Савчук, передм. М. Д. Павлюк, Київ-Косів 2012, с. 5, 98.

5 Див.: Модне слівце: Чічка, значення слова, [в:] Електронний ресурс: www.uamodna.com/ articles/chichka (доступ: 15.11.2014).

${ }^{6}$ Див.: І. Я. Франко, Перехресні стежки, [в:] Його ж, Твори, у 20 томах, т. 7: Повісті, ред. О. Є. Корнійчук, Київ 1951, с. 294.

${ }^{7}$ Г. Хоткевич, Камінна душа, [в:] Його ж, Твори, у 2 томах, т. 2, Київ 1966, с. 63.

${ }^{8}$ В. Стефаник, Сини, [в:] Його ж, Мос слово. Новели, оповід., автобіогр. та критич. матеріали, витяги з листів, упоряд., передм. та приміт. Л. Дем'янів ської, Київ 2001, с. 31.
} 
висловлює бажання: Як умру, то най на моїм полі чічки ростуть та най своїми маленькими головками кажуть отченаш за діда ${ }^{9}$.

Другий з Покутської трійці письменників - це Марко Черемшина, який створив новелу з промовистою назвою Чічка (1901). Чічка (заголовок твору) стара кобила, яка вмирає від надсильної довголітньої праці, залишаючи сім'ю сільських бідняків у безвиході. У новелі віддзеркалена щира прив'язаність людини до тварини, ніжність почуттів, що репрезентується в наративній формі голосінням гуцула над вірною кониною. Лексема Чічка функціює і як власна назва, зокрема в позиції звертання, повторюється багаторазово: - То ти мні, Чічко, лишєєш, самого серед бойків лишєєш?; - То такими-сми ті отавами візимував, то таксми ті, Чічко, вікохав?; Не кривдуйси на мні, моя Чічко, не кривдуй, шо ти упаласи в пусті руки, у лєитий рід!10.

У повісті Крізь дим $i$ згарь (1928) галицького письменника Миколи Матієва-Мельника гуцульське село змальоване в трьох часопросторових проекціях: до, під час і після війни. Туга за спокійними часами відображена в повісті за допомогою традиційних гуцульських атрибутів і зокрема 'чічки': По-nid дими арештанти... Минали брід, куди маржину гнали. / То бувало - любо: з чічками, співанка... Іили останній кусень дороги — останні кроки до гробу ${ }^{11}$.

Чічку як дарунок на прощання вживають і в мінорних стрілецьких піснях, зокрема у творі з назвою Синя чічка (Як ішов, лишив дівчині синю чічку, / Та й пішов, пропав донині: камінь в річку ${ }^{22}$ ) Василя Бобинського. "Синя чічка", використана поетом у рядках приспіву, традиційно символізує любов і вірність стрільця своїй коханій, надію на повернення. Однак тяжка доля стрільця: він гине за Україну на далекій чужині.

У романі Чорногора говорить (1931) Михала Козоріса гуцулка Явдоха, висловлюючи захоплення хрещеною дитиною, традиційно порівнює іiі з квіткою - чічкою: Та щуоб, Ивко сестричко, ти подужала скоро та аби путерії набрала, та аби викохала свого Михайлика, аби з його виріс легінь на все село й на всю верховину. Ой бож дитинка у тебе, йик чічка, йик самий иукерок!"13.

В оповіданні На полонині (1932) Лесі Верховинки головний герой Олекса Миронюк, зізнаючись у любові, подумки називає свою кохану “чічкою прекрасною": Марусе, моя чічко прекрасна, моя княгинько золота... ${ }^{14}$.

Поміж письменників, які з любов'ю змальовували неповторну красу Гуцульщини, використовуючи гуцульський говір, був і Володимир Гжицький. У його романі Опришки (1962) рослинний світ Гуцульщини репрезентований низкою діалектних лексем, зокрема і словом чічка, порівн.: [...] a на узбіччях синіли чічки $і$ змагалися синявою з високим небом ${ }^{15}$.

Гуцульські побутовізми, серед яких і слово чічка у прозових творах використовував Сидір Воробкевич. У його оповіданнях чічка — це вид прикраси гу-

${ }^{9}$ Там само, с. 197.

${ }^{10}$ М. Черемшина, Чічка, [в:] Його ж, Новели. Оповідання. Поезія. Переклади. Літературно-критичні виступи. Спогади. Автобіографія, ред. Р. В. Мишанич, Київ 1987, с. 82.

${ }_{11}$ Див.: М. Матіїв-Мельник, Крізь дим i згарь, [в:] Його ж, Твори, Львів 1995, с. 340.

12 Див. В. Бобинський, Синя чічка, [в:] Нам воно святе! Співаник Українських січових стрільців, Електронний ресурс: img.yakaboo.ua/media/mediagallery/pdf/1/1/111i_6.pdf(12.02.2018).

${ }_{13}^{13}$ М. Козоріс, Чорногора говорить, Повість, передм. Й. Курбаса, Харків 1931, с. 232.

14 Див.: Л. Верховинка, До Делятина на крилах мрій: Поезї, новели, драматичні твоpu, есеї, статmi, епістолярій, упоряд. О. О. Жарівський, вступ. слово М. І. Гнатюка; опр. М. Маринюка, Львів 2013, с. 170.

15 В. Гжицький, Опришки [в:] Його ж, Опришки. Кармалюк: історичні романи, Львів 1971, c. 17. 
цульського одягу: [...] носив він крисаню і ще до того украшену павами $і$ чічками, вишиваний киптар, черчиком крашені гачі, — от став наш Сруль правдивим, вірним моделем нашого верховиния-Гуцула ${ }^{16}$.

У циклі легенд, серед яких і Легенда про Галині дружечки (1955), у функціях прикладок використано звертання, що слугує для характеристики героїнь (порівн.: Гафійко-Любко, Параню-красотко, Катерино-золотко, Ганусюяблучко красне). Віра Вовк застосовує й прикладку чічка (Сленко-чічко) ${ }^{17}$. Так само і в Різдвяній летенді (1955) письменниця актуалізує це народнопоетичне звертання до сироти Марії, яка уособлює Марію-Богородицю, напр.: Нá тобi ліскових горішків, чічко! Молися за нас грішних ${ }^{18}$.

У всіх указаних вище прикладах діалектизм чічка має позитивну конотацію, “випромінює” добру енергетику, його використання сприяє ліризації мовлення.

Василь Ткачук (1916-1944) $)^{19}$ — донедавна призабутий, вельми талановитий український новеліст 30-х років XX ст. так само, як і його великі попередники Василь Стефаник чи Марко Черемшина, походить з Покутського краю (новеліст народився і провів свої молоді літа в селі Іллінці Снятинського повіту, що розташоване неподадік Русова - рідного села Василя Стефаника - i Снятиня, де жив і помер Марко Черемшина). Отже, не дивує факт, що у своїй творчості письменник використовував покутський діалект, на що, до речі, звернули увагу вже його ранні критики ${ }^{20}$. Серед численних діалектизмів, ужитих письменником, особливу увагу привертає слово чічка, що в новелістиці В. Ткачука відіграє першорядну роль, досягаючи ступеня багатозначного символу.

Чічка винесена в заголовок дебютної збірки Ткачука (Сині чічки, 1935), що удостоєна звання "Найкраща книжка за 1935 р." 21 . Через майже вісімдесят років у 2013-му старанням дочки письменника Ольги Гоффманн, яка проживає в Щецині (Польща), видано книжку під назвою Сині чічки (2013), у якій зібрано новели з усіх чотирьох прижиттєвих видань прозаїка ${ }^{22}$. Серед майже шістдесяти зразків "малої прози” в згаданій збірці є окрема новела Сині чічки, де розповідається про мужиків, які несли на гріб загиблого вояка новий “ціментовий”, “мальований хрест”. Сині чічки, використані в позиції заголовку твору, — це квітки, що викохалися на могилі стрільия ${ }^{23}$. Прикметно те, що сині чічки порос-

${ }^{16}$ Див.: Твори Ізидора Воробкевича, у 2 томах, упоряд., вступна ст. та загал. замітки О. Маковея, т. 2: Оповідання, Львів 1911, с. 203.

${ }^{17}$ Див.: В. Вовк, Летенда про Галині дружечки, [в:] ІЇ̈ ж, Проза, Київ 2001, с. 385.

${ }^{18}$ Див.: В. Вовк, Різдвяна летенда, [в:] ІЇі ж, зазнач. джер., с. 382.

19 Примітка. Про складний життєвий шлях новеліста, а також художні особливості його творчості див. статті: A. Horniatko-Szumiłowicz, ,, Skromne obrazki wiejskie” Wasyla Tkaczuka (Szkic do portretu pisarza zapomnianego), [w:] „Studia et Documenta Slavica”, 2017, nr 1, red. J. Czaplińska, c. 9-21; A. Горнятко-Шумилович, Буря Василя Ткачука (Про забуту новелу „Загубленого таланту”), [w:] „Studia Ukrainica Posnaniensia”, 2018, zeszyt VI, c. 197-205.

${ }^{20}$ Примітка. Український видавець, публіцист, етнограф і поет Олександр Мох опублікував в 1936 році під псевдонімом С. Лишкевич на сторінках літературно-мистецького місячника “Дзвони” рецензію на дебютну книжку Ткачука. О. Мох критично ставився до "народної мови" молодого новеліста, наголошуючи, між іншим, що „Ткачук занадто захоплюється говором і вживає його навіть у своїм власнім оповіданню, не лише в розмовах своїх героїв, і то вживає включно зі всіма варваризмами”. Див.: С. Лишкевич (О. Мох), Рещензія на книжку: В. Ткачук, Сині чічки: Нариси. Львів 1935, [в:] „Дзвони”, 1936, ч. 1/2, с. 74-75.

${ }^{21}$ Див.: Х. Синітович, Життевий і творчий шлях Василя Ткачука, [в:] В. Ткачук, Сині чічки. Новели, передм. Х. Синітович, Івано-Франківськ 2013, с. 9.

${ }^{22}$ Примітка. За життя Василя Ткачука були видані чотири збірки новел: Сині чічки (1935), Золоті дзвінки (1936), Зимова мелодія (1938), Весна (1940).

${ }^{23}$ В. Ткачук, Сині чічки. Новели, передм. Х. Синітович, Івано-Франківськ 2013, с. 113. 
тають могилу, поруч барвінку - символу невмирущої вічної пам'яті про покійних (...Могила привітала їх вклоном барвінку й синіх чічок $\left.{ }^{24}\right)$.

Вони, як правило, персоніфіковані (бистро й цікаво приглядались; питались шибаючих птищь та рівних піль ${ }^{25}$ ), мають позитивну конотацію, підсилену відповідними епітетами (малі вони й чепурні - Богом милувані ${ }^{26}$ ) й порівняннями (сині чічки єго [гріб - А. Г.-Ш.] вкрасили, як чисте небо; подобали на укішних школяриків по добрій клясі ${ }^{27}$ ). Фраза у кровиі змочені, кровиею поєні ${ }^{28}$, повторювана в перших й останніх рядках новели, звучить як приспів, свідчить про важливість указаної художньої деталі, що символізує пам'ять, має вагоме змістове навантаження, збуджує думку, викликає в уяві читача цілісну картину й низку асоціацій.

У згаданій вище книжці 2013 року, у яку ввійшли всі новели Василя Ткачука, крім кількох непублікованих творів, що зберігаються в архіві дочки письменника Ольги Гоффманн (Забухтувавси; Правдивий поет; Підпал; Трембіта кличе; Віно; Гуляла Маруся; До Бразилї̈; За невістку Яковихи) $)^{29}$, слово чічка вжите приблизно двадцять разів, не враховуючи назв збірки й окремої новели.

Характерно те, що чічки у Василя Ткачука не лише сині, як простежуємо в сильних позиціях заголовку двох збірок й однієї окремої новели, але й білі, мотив яких він використав у трьох творах: Гріх, Флояра грає, Останні гони. Обидва кольори мають позитивну символіку. За українською міфологією, синій — це „колір небесного простору і моря. У ньому - таїна пізнання світу. Символізує чесність, добру славу, вірність”зо; білий - „колір чистоти, невинності, радості. [...] пов'язаний з денним світлом, а значить із життям"з1. Так, старий Стефан з новели Флояра грає тужить за померлою жінкою, згадуючи подружнє життя, спорідненість їхніх душ, що порівнюються до білих чічок, напр.: $\mathrm{Hi}$ мольфар, ні щезник їх не брався. Ні громи, ні повені їх не лякали; бо в них чисті душі були, як білі чічки, мов випрана сорочка ${ }^{32}$.

Водночас обидві барви пов'язані з образом смерті. Як підкреслюють дослідники, „на Галичині під час жалоби пов’язували голову чорними аби синіми хустинками" ${ }^{3}$. Білий — „це стародавній колір жалоби, коли вдягали покійників у біле та покривали білим саваном. У білій одежі з'являються людям примари та мерці" ${ }^{34}$. Така сама символіка вказаних кольорів наявна й у творах В. Ткачука. Так, у новелі Останні гони в умираючого Федора помітні всі ознаки згаслого життя, зокрема очі скляні, порожні, прозорі ставали як білі чічки ${ }^{35}$.

\footnotetext{
${ }^{24}$ Там само, с. 114.

25 Там само, с. 113.

${ }^{26}$ Там само, с. 113 .

${ }^{27}$ Там само, с. $113,115$.

28 Див.: Там само, с. 113, 115. хів Ольги Гоффманн.

30 Див.: В. Войтович, Українська міфологія, Київ 2002, с. 473.

${ }^{31}$ Там само, с. 472.

${ }^{32}$ В. Ткачук, Флояра грає, [в:] Його ж, зазнач. джер., с. 68.

${ }^{33}$ Див.: В. Войтович [в:] Його ж, зазнач. джер., с. 473.

${ }^{34}$ Там само, с. 472.

${ }^{35}$ В. Ткачук, Останні гони, [в:] Його ж, зазнач. джер., с. 105.
}

29 Примітка. У непублікованих творах Василя Ткачука діалектизм чічка вжитий тільки один раз. У новелі Трембіта кличе, у якій розповідається про побудову нової сільської читальні, слово чічка використане як об'єкт порівняння: Легіні, як олені новий будинок майструють, як чічку будують. Для покутського новеліста чічка традиційно має позитивну конотацію й означає дбайливість і самовіддачу народних майстрів. Див.: В. Ткачук, Трембіта кличе, [в:] Приватний ар- 
Однозначно позитивна конотація діалектизму чічка виражена шляхом використання порівняльних конструкцій. Слово чічка виступає в них об'єктом (напр.: нашпанувався, як чічка до сония; чисті душі [...], як білі чічки; „сусідсъкі хати [...], щзо як чічки в збанчіку"), або суб' єктом порівняння (порівн.: сині чічки єго вкрасили, як чисте небо; Сині чічки [...] подобали на укішних школяриків по добрій клясі) ${ }^{36}$.

Чічка у текстах В. Ткачука - нероздільний елемент гуцульського ландшафту. Напр., удовець Стефан з новели Флояра грає намагається заглушити нестерпну тугу за померлою жінкою, перебуваючи поміж чарівних гір: Сів на карбований камінь, на горбатому, як і він, труні, але зеленому, чічками обтиканому, стежками вперезаному, на питомій царині, на вузькій нивиі ${ }^{37}$.

Традиційно для поетики Ткачука природне довкілля з його нероздільним компонентом (чічками) суголосне діям та переживанням героїв. Так, коли батько з новели Пструги рішився на крадіжку заголовних панських пстругів, щоб нагодувати голодних дітей, природа стає свідком цього й супроводжує героя: $n i$ шов, як води йдуть... Дебрами томився, вереском річок лютився, у чічки, росою купані, шпотався... ${ }^{38}$. У новелі Яблуко голодний Андрусь, який надкусив яблуко, що його разом з братом роздобули для вмираючої матері, відчуває провину. Дитяча кривда і трагізм відображені крізь призму паралелізму: страждає дитина й природа: Йшов [Андрусь - А. Г.-Ш] понад окіп і ломив верики травам та будякам, а чічкам так само ${ }^{39}$. Так само герой Семен Дідушків (Віддай ниву!), у якого багач Онуфрій забрав жінку й ниву, відчуває кривду, на що реагує природа: Над Карпатами горою по хмариі, долом по чічиі, а деревами по птичиі. Все наче настроржилось, щзоб зрозуміти його ${ }^{40}$.

Іншим разом гірське довкілля, невід'ємним елементом якого є чічки, “осолоджує” нелегке життя молодого героя Степанка (Черешні), який примушений кинути школу, що її він „так любив”, й „обробляти поля” для „багачиська”. Щоб полегшити надмірну працю гімназиста, земна краса скоботала його [...]. До нього чічки й браві загони всміхалися й дерева збирали запах $і$ кидали йому ${ }^{41}$.

Чічка у творах Ткачука — це не лише важливий компонент українського ландшафту, але й різновид емоційно забарвленого звертання до близької серцю людини. Напр., в одному з найдовершеніших зразків “малої прози” В. Ткачука Бурi, зраджений у коханні герой проявляє полюсні почуття стосовно невірної дружини, що відображені й у мовленні. Він безжально картає їі, уживаючи образливі слова: стямся, лєщта суко, і водночас герой звертається до жінки з непідробною любов'ю і ніжністю, використовуючи діалектизм чічка, що є символом жіночої краси, делікатності, виявом чоловічої любові, порівн.: „Дзвінко, чічко моя!" 42 . Так само і в новелі Чорні хліби мати пробачає всі образи дорослому синові, звертаючись до нього з промовистими словами: Чічко моя!43. У слові чічка міститься щира материнська любов і ласка до рідної дитини.

У творах В. Ткачука чічка супроводжує людину протягом усього іiі життя. Вона відіграє помітну роль під час важливих подій. Напр., у новелі Тато

\footnotetext{
${ }^{36}$ Див. В. Ткачук, [в:] Його ж, зазнач. джер., с. 44, 69, 83, 113, 115.

${ }^{37}$ В. Ткачук, Флояра грає, [в:] Його ж, зазнач. джер., с. 69.

${ }^{38}$ В. Ткачук, Пструги, [в:] Його ж, зазнач. джер., с. 87.

${ }^{39}$ В. Ткачук, Яблуко, [в:] Його ж, зазнач. джер., с. 161.

${ }^{40}$ В. Ткачук, Віддай ниву!, [в:] Його ж, зазнач. джер., с. 167.

${ }^{41}$ В. Ткачук, Черешні, [в:] Його ж, зазнач. джер., с. 178.

${ }^{42}$ В. Ткачук, Буря, [в:] Його ж, зазнач. джер., с. 163.

${ }^{43}$ В. Ткачук, Чорні хліби, [в:] Його ж, зазнач. джер., с. 171.
} 
ŭ одинак заголовний одинак, який збирається вирушити на війну, одягає сороч$\kappa y$, світошну, окрайку писану, $і$ чоботи шаворові $i^{44}$. Це переломна подія в житті молодого Василя, саме тому хлопець зібрався, як пава, і нашпанувався, як чічка до сония $\AA^{45}$.

Чічка - невід'ємний супутник урочистостей і свят. Так, у час Великодня, коли народ поспішає до церкви (Гріх), вулииями повага, хатами мир, полями білі чічки й птахи [... ${ }^{46}$. Так само в новелі Чорні хліби Великдень це пора всепрощення, миру, радості, на що відгукується довкілля і чічки зокрема. Коли люди напливали до иерковиі, соковиті облаки всміхалися. Чічки иілуввали їх по ногах та кланялись, та веселилися ${ }^{47}$.

I, урешті, чічка підноситься у В. Ткачука до рівня народного символу. У новелі Акаиї̈ пахнуть головний герой, солдат-каліка, роздумує про свою нелегку долю борця за Батьківщину: Та ж я одружився з тою співанкою [Гей, у лузі черво!... - А. Г.-Ш.], щуо з великого роду, та гербу праславного походить; що дочкою є вельможної княгині, що всі чі чічки, акачїі, черемхи, дуби й вся деревина; й земля: лани й горби, ріки й стави ї̈. А вона Україна називається!... [...] Тота, що через Неї я став калікою ${ }^{48}$.

Символ - це предметний або словесний знак, що опосередковано виражає сутність певного явища й має філософську смислову наповненість ${ }^{49}$. Поміж багатої скарбниці символів української культури є і квіткова символіка. Важливими символами в Україні стали калина, верба, барвінок, волошки, вишня, євшанзілля, жито, мак, тополя, яблуня, мальва, конвалія, рута-м'ята, лобода та ін. До цього списку можна зарахувати й символ гірської квітки - чічки, що знайшов віддзеркалення у творчості письменників Покуття, Буковини та Галичини i, зокрема, в новелістиці “загублениго таланту” Василя Ткачука. I коли в одному з його маленьких прозових шедеврів - згадуваній уже новелі Останні

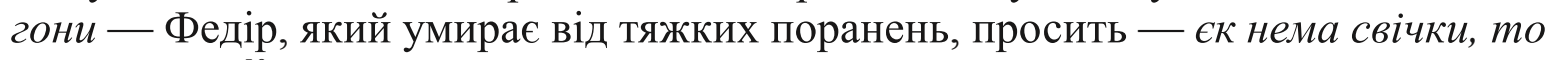
урвіт' чічку ${ }^{50}$, зрозуміло, що біла або синя гірська квітка більше важить для гуцулів, ніж ритуальний атрибут під час проводів у вічну путь. Чічка - це священний код гуцульського роду, що відіграє роль оберегу, який супроводжує гуцулів, немов вишивка, у часи радості й смутку. Це віртуозно живописав словом Василь Ткачук.

\section{Список використаної літератури}

Бикова Т. Б., ,, Верховино, світку ти наш... ” : гуиульський текст украӥнської літератури першої третини ХХ століття, моногр., Київ 2015.

Бобинський В., Синя чічка, [в:] Нам воно святе! Співаник Українських січових стрільців, Електронний ресурс: img.yakaboo.ua/media/mediagallery/pdf/1/1/111i_6. $\operatorname{pdf}(12.02 .2018)$.

Верховинка Л., До Делятина на крилах мрій: Поезї, новели, драматичні твори, есеї, cmammi, епістолярій, упоряд. О. О. Жарівський, вступ. слово М. І. Гнатюка; опр. М. Маринюка, Львів 2013.

\footnotetext{
${ }^{44}$ В. Ткачук, Тато й одинак, [в:] Його ж, зазнач. джер., с. 44.

${ }^{45}$ Там само.

${ }^{46}$ В. Ткачук, Гріх, [в:] Його ж, зазнач. джер., с. 157.

${ }^{47}$ В. Ткачук, Чорні хліби, [в:] Його ж, зазнач. джер., с. 170.

${ }^{48}$ В. Ткачук, Акачії пахнуть, [в:] Його ж, зазнач. джер., с. 155.

49 Див.: Літературознавчий словник-довідник, ред. кол., Р. Т. Гром'як, Ю. І. Ковалів та ін., Київ 1997, с. 635-636.

${ }^{50}$ В. Ткачук, Останні гони, [в:] Його ж, зазнач. джер., с. 106.
} 
Вовк В., Летенда про Галині дружечки, [в:] Її ж, Проза, Київ 2001.

Вовк В., Різдвяна летенда, [в:] Ії̈ ж, Проза, Київ 2001.

Войтович В., Українська міфологія, Київ 2002.

Гжицький В., Опришки [в:] Його ж, Опришки. Кармалюк: історичні романи, Львів 1971.

Горнятко-Шумилович А., Буря Василя Ткачука (Про забуту новелу „, Загубленого таланmy”), [w:] „Studia Ukrainica Posnaniensia”, наук. ред. Т. А. Космеди, 2018, zeszyt VI, c. $197-205$.

Грещук В., Гуцульський діалект у мові сучасної украӥнської літератури, [в:] „Вісник Прикарпатського національного університету. Філологія", гол. ред. В. В. Грещук, 2012, вип. XXXII-XXXIII, c. 214-219.

Козоріс М., Чорногора говорить, Повість, передм. Й. Курбаса, Харків 1931.

Лишкевич С. (Мох О.), Рецензія на книжку: В. Ткачук, Сині чічки: Нариси. Львів 1935, [в:] „Дзвони”, 1936, Ч. 1/2, с. 74-75.

Літературознавчий словник-довідник, ред. кол., Р. Т. Гром’як, Ю. І. Ковалів та ін., Київ 1997.

Матіїв-Мельник М., Крізь дим і згарь, [в:] Його ж, Твори, Львів 1995.

Модне слівие: Чічка, значення слова, [в:] Електронний ресурс: www.uamodna.com/articles/chichka (15.11.2014).

Словник українських говірок карпатського регіону: Пояснення та походження слів, уклад. Д. Савчук, передм. М. Д. Павлюк, Київ-Косів 2012.

Словник української мови, в 11 томах. за ред. І. К. Білодіда, Київ 1970-1980, т. 11, 1980.

Стефаник В., Сини, [в:] Його ж, Моє слово. Новели, оповід., автобіогр. та критич. матеріали, витяги з листів, упоряд., передм. та приміт. Л. Дем’янівської, Київ 2001.

Твори Ізидора Воробкевича, у 2 томах, упоряд., вступ. ст. та загал. замітки О. Маковея, т. 2: Оповідання, Львів 1911.

Ткачук В., Сині чічки. Новели, передм. Х. Синітович, Івано-Франківськ 2013.

Ткачук В., Трембіта кличе, [в:] Приватний архів Ольги Гоффманн.

Франко І. Я., Перехресні стежки, [в:] Його ж, Твори, у 20 томах, т. 7: Повісті, ред. О. Є. Корнійчук, Київ 1951.

Хоткевич Г., Камінна душа, [в:] Його ж, Твори, у 2 томах, т. 2, Київ 1966.

Черемшина М., Чічка, [в:] Його ж, Новели. Оповідання. Поезія. Переклади. Літературнокритичні виступи. Спогади. Автобіографія, ред. Р. В. Мишанич, Київ 1987.

Horniatko-Szumiłowicz A., , Skromne obrazki wiejskie” Wasyla Tkaczuka (Szkic do portretu pisarza zapomnianego), [w:] „Studia et Documenta Slavica”, red. J. Czaplińska, 2017, nr 1, red. J. Czaplińska, s. 9-21.

\section{Spysok vykorystanoi literatury [References]}

Bykova T. B., ,, Verkhovyno, svitku ty nash..." : hutsulskyi tekst ukrainskoi literatury pershoi tretyny XX stolittia ["Verkhovyno, our World...": Hutsul Text of Ukrainian Literature of the First Third of the XXth Century], monohr., Kyiv 2015.

Bobynskyi V., Synia chichka [Blue Chichka], [v:] Nam vono sviate! Spivanyk Ukrainskykh sichovykh striltsiv, [v:] Elektronnyi resurs: img.yakaboo.ua/media/mediagallery/ pdf/1/1/111i_6.pdf (12.02.2018).

Verkhovynka L., Do Deliatyna na krylakh mrii: Poezii, novely, dramatychni tvory, esei, statti, epistoliarii [To Deliatyn on Wings of dream: Poetry, Dramatic Works, Essay, Articles, Epistolary Works], uporiad. O. O. Zharivskyi, vstup. slovo M. I. Hnatiuka, opr. M. Maryniuka, Lviv 2013.

Vovk V., Legenda pro Halyni druzhechky [Legends about Halyna's Druzhechky], [v:] Yii zh, Proza, Kyiv 2001.

Vovk V., Rizdviana legenda [Christmas Legend], [v:] Yii zh, Proza, Kyiv 2001.

Voitovych V., Ukrainska mifolohiia [Ukrainian Mythology], Kyiv 2002. 
Hzhytskyi V. , Opryshky [v:] Yoho zh, Opryshky. Karmaliuk: istorychni romany, Lviv 1971.

Horniatko-Shumylovych A., Buria Vasylia Tkachuka (Pro zabutu novelu „Zahublenoho talantu”) [Storm of Vasyl Tkachuk (About Forgotten Novel “Lost Talent”)], [w:] „Studia Ukrainica Posnaniensia”, red. nauk. T. Kosmeda, 2018, zeszyt VI, s. 197-205.

Greshchuk V., Hutsulskyi dialekt u movi suchasnoi ukrainskoi literatury [Hutsul Dialect in Language of Modern Ukrainian Literature], [v:], ,Visnyk Prykarpatskoho natsionalnoho universytetu. Filolohiia", hol. red. V. V. Greshchuk, 2012, vyp. XXXII-XXXIII, s. 214219.

Kozoris M., Chornohora hovoryt [Chornohora Speaks], Povist, peredm. Y. Kurbasa, Kharkiv 1931.

Lyshkevych S. (Mokh O.), Retsenziia na knyzhku: V. Tkachuk, Syni chichky: Narysy. Lviv 1935 [Review on the Book: V. Tkachuk, Syni chichky: Sketches. Lviv 1935], [v:] „Dzvony”, 1936, Ch. 1/2, s. 74-75.

Literaturoznavchyi slovnyk-dovidnyk [Literature Studies Dictionary], red. kol., R. T. Hromiak, Yu. I. Kovaliv ta in., Kyiv 1997.

Matiiv-Melnyk M., Kriz dym i zghar [Through Smoke and Fire], [v:] Yoho zh, Tvory, Lviv 1995.

Modne slivtse: Chichka, znachennia slova [Chichka, Meaning of Word], [v:] Elektronnyi resurs: www.uamodna.com/articles/chichka (15.11.2014).

Slovnyk ukrainskykh hovirok karpatskoho rehionu: Poiasnennia ta pokhodzhennia sliv [Dictionary of Ukrainian Dialects of Carpathian Region: Explanation and Etymology of Words], uklad. D. Savchuk, peredm. M. D. Pavliuk, Kyiv-Kosiv 2012.

Slovnyk ukrainskoi movy [Ukrainian Language Dictionary], v 11 tomakh., za red. I. K. Bilodida, Kyiv 1970-1980, t. 11, 1980.

Stefanyk V., Syny [Sons], [v:] Yoho zh, Moie slovo. Novely, opovid., avtobiohr. ta krytych. materialy, vytiahy z lystiv, uporiad., peredm. ta prymit. L. Demianivskoi, Kyiv 2001.

Tvory Izydora Vorobkevycha [Izydora Vorobkevych's Works], u 2 tomakh, uporiad., vstup. st. ta zahal. zamitky O. Makoveia, t. 2: Opovidannia, Lviv 1911.

Tkachuk V., Syni chichky. Novely [Blue chichky], peredm. Kh. Synitovych, Ivano-Frankivsk 2013.

Tkachuk V., Trembita klyche [Trembita is Calling], [v:] Pryvatnyi arkhiv Olhy Hoffmann.

Franko I. Ya., Perekhresni stezhky [Crossing Paths ], [v:] Yoho zh, Tvory, u 20 tomakh, t. 7: Povisti, red. O. Ye. Korniichuk, Kyiv 1951.

Khotkevych H., Kaminna dusha [Stone Soul], [v:] Yoho zh, Tvory, u 2 tomakh, t. 2, Kyiv 1966.

Cheremshyna M., Chichka, [v:] Yoho zh, Novely. Opovidannia. Poeziia. Pereklady. Literaturno-krytychni vystupy. Spohady. Avtobiohrafiia, red. R. V. Myshanych, Kyiv 1987.

Horniatko-Szumiłowicz A., ,Skromne obrazki wiejskie” Wasyla Tkaczuka (Szkic do portretu pisarza zapomnianego), [w:] „Studia et Documenta Slavica”, red. J. Czaplińska, 2017, nr 1, s. 9-21. 